\title{
WORKSHOP VIRTUAL PENGEMBANGAN DESAIN PEMBELAJARAN JARAK JAUH
}

\author{
Durrotun Nafisah, Abd. Ghofur, Ninies Eryadini, Kuswanto, Evi Aulia Rachma, \\ Ety Youhanita, Ahmad Sidi \\ Universitas PGRI Adi Buana Kampus Lamongan, Indonesia \\ na.vius07@gmail.com
}

\begin{abstract}
This PKM is implemented to facilitate teachers in designing distance learning in the new normal era. This PKM uses a participatory method, participants take part in a whole series of activities, both delivering material and independent assignments. All material is delivered virtually through the Zoom Cloud Meeting application considering that it is still in the period of the Covid-19 pandemic. Participants who take part in the workshop can access the material via zoom, live facebook and live streaming youtube. As many as 300 participants who took part in this PKM activity, it is known that most (73\%) of the participants came from elementary schools (SD) and $14 \%$ came from junior high schools (SMP), the rest came from kindergartens, high schools and universities. Based on the results of the activity, most of them understand the concept of distance learning and are able to develop distance learning designs. Participants are able to develop distance learning tools, namely lesson plans and learning teaching materials in offline, bold or combination form. $100 \%$ of participants submit assignments to make lesson plans and teaching materials through google classroom. Some participants are also able to operate media and evaluate digital learning because in the 2013 curriculum teachers are also expected to be able to master and apply technology in the learning process to meet the millennial generation.
\end{abstract}

Keywords: workshop, virtual, design, distance learning

\begin{abstract}
Abstrak
PKM ini dilaksanakan untuk memfasilitasi guru dalam mendesain pembelajaran jarak jauh di era new normal. PKM ini menggunakan metode partisipatif, peserta mengikuti penuh seluruh rangkaian kegiatan, baik penyampaikan materi maupun tugas-tugas mandiri. Seluruh materi disampaikan secara virtual melalui aplikasi Zoom Cloud Meeting mengingat masih dalam masa pandemic covid-19. Peserta yang mengikuti workshop dapat mengakses materi melalui zoom, live facebook dan live streaming youtube. Diketahui peserta yang mengikuti kegiatan PKM ini sebagian besar (73\%) berasal dari sekolah tingkat dasar (SD) dan $14 \%$ berasal dari sekolah menengah pertama (SMP), sisanya berasal dari TK,SMA dan Perguruan Tinggi. Berdasarkan hasil kegiatan bahwa sebagian besar peserta memahami konsep pembelajaran jarak jauh dan mampu mengembangkan desain pembelajaran jarak jauh. Peserta mampu mengembangkan perangkat pembelajaran jarak jauh yaitu RPP dan bahan ajar pembelajaran dalam bentuk luring, daring maupun kombinasi. $100 \%$ peserta mengumpulkan tugas membuat RPP dan bahan ajar melalui google classroom. Sebagian peserta juga mampu dalam mengoperasikan media dan evaluasi pembelajaran digital karena pada kurikulum 2013 guru juga diharapkan mampu menguasai dan menerapkan teknologi dalam proses pembelajaran untuk menyongsong generasi milenial.
\end{abstract}

Kata Kunci: workshop, virtual, desain, pembelajaran jarak jauh

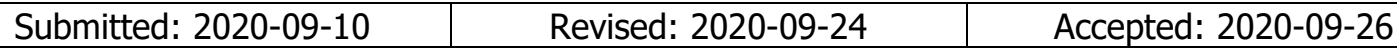

\section{Pendahuluan}

Dunia saat ini dilanda oleh virus corona Covid 19, virus ini merupakan keluarga besar virus yang menyebabkan penyakit pada manusia dan hewan yang menyebabkan gejala ringan sampai berat. Covid 19 ditemukan di Wuhan, Hubei, China pada tahun 2019 
dan diberi nama Corona virus disease-2019 yang disingkat menjadi COVID-19 (Ilmiyah, 2020; Hui, et al., 2020). WHO menetapkan sebagai kedaruratan kesehatan masyarakat yang meresahkan dunia pada tanggal 30 Januari 2020. Indonesia melaporkan kasus konfirmasi COVID-19 pada bulan Maret 2020. Dengan adanya Covid 19 memberikan dampak bagi semua sector tak terkecuali sector pendidikan. Pada tanggal 18 Maret 2020 pemerintah mengeluarkan surat edaran (SE) untuk tidak mengadakan kegiatan diluar dan didalam ruangan untuk mengurangi penyebaran covid 19 terutama sektor pendidikan (Dewi, 2020). Menteri pendidikan dan kebudayaan mengeluarkan Surat Edaran Nomor 4 Tahun 2020 Pada tanggal 24 maret 2020 yang intinya bahwa proses belajar dilaksanakan dirumah dengan mengfokuskan pendidikan kecakapan hidup mengenai pandemic covid-19 melalui pembelajaran jarak jauh. Kebijakan tersebut terus berlangsung sampai diperkuat dengan surat edaran Nomor 15 Tahun 2020 tentang Pedoman Penyelenggaraan Belajar dari Rumah dalam Masa Darurat Penyebaran Corona Virus Disease (Covid-19).

Dalam menghadapi pembelajaran di era New Normal diperlukan keterampilan dalam menyusun perangkat pembelajaran. Pembelajaran yang digunakan adalah pembelajaran via daring/online, Luring maupun kombinasi sehingga sangat dibutuhkan keahlian dalam teknologi dan informasi. Seorang guru harus dapat memilih, membuat, menggunakan dan mengembangkan format RPP, penyusunan RPP sangat penting dalam persiapan proses pembelajaran yang akan digunakan. Dalam pelaksanaan pembelajaran jarak jauh harus memiliki persiapan yang matang baik dalam hal desain progam (kegiatan daring/luring/kombinasi), regulasi (kurikulum, hasil yang dicapai dan penetapan batasan) maupun sarana prasarana (paket internet, LKS). Hal ini sangat penting karena guru dan siswa terpisah oleh ruang dan waktu tetapi harus memiliki komunikasi yang interaktif antara guru, siswa dan sumber belajar. Selain itu, dibutuhkan juga kesabaran, komitmen, keuletan, pemahaman serta keterampilan dalam penggunaan teknologi agar tujuan pembelajaran jarak jauh bisa tercapai (Sa'adah, 2020).

Dunia pendidikan menjadi salah satu perhatian Pemerintah di tengah pandemic covid-19. Pemerintah sangat menekankan akan keselamatan dan kesehatan peserta didik, pendidik, tenaga kependidikan, beserta keluarga dan masyarakat sekitar. Oleh sebab itu satuan pendidikan yang berada pada zona kuning, oranye dan merah dilarang melakukan kegiatan pembelajaran secara tatap muka di sekolah. Satuan pendidikan yang berada pada zona hijau diizinkan untuk melakukan kegiatan pembelajaran secara tatap muka di kelas tetapi dengan syarat harus mematuhi protocol kesehatan. Banyaknya sekolah yang berada di zona merah, kuning dan hijau maka desain pembelajaran jarak jauh dan tatap muka harus menjadi perhatian khusus bagi peserta didik. Salah satunya adalah harus mempersiapkan perangkat pembelajaran jauh yang disesuaikan dengan kondisi disetiap satuan pendidikan masing-masing. Perangkat pembelajaran yang akan disampaikan di pengabdian masyarakat ini adalah RPP, Media Pembelajaran dan asesmen pembelajaran berbasis daring, luring dan kombinasi.

Pada saat ini semua komponen pendidikan beradaptasi dengan keadaan era new normal dengan mematuhi aturan dari pemerintah. Adaptasi ini diartikan sebagai cara pandang dan perilaku baru yang nantinya menjadi budaya baru (Nuryatin, 2020). Jadi new normal dapat dimaknai hidup berdampingan dengan covid-19. Sehingga keluarlah 
Surat Edaran No.15 Tahun 2020. Dengan adanya pandemic covid-19 mampu mendorong perkembangan dunia pendidikan kearah lebih baik. Hal ini dilihat dari metode pembelajaran yang beragam dan memanfaatkan teknologi saat ini. Adapun aplikasi yang menunjang proses pembelajaran diantaranya zoom meeting, google classroom, whatsapp, facebook, massager dan lain sebagainya. Jika keadaan sebelum adanya pandemic covid19 guru melihat kulaitas siswa berdasarkan satu kelas, maka di era new normal ini guru melihat kualitas peserta didiknya satu persatu dengan tujuan guru melihat potensi siswanya terutama potensi dalam penggunaan teknologi (Firmansyah, Y., \& Kardina, 2020). Jadi salah satu materi dalam pengabdian masyarakat ini adalah media pembelajaran baik untuk pembelajaran daring, luring maupun kombinasi. Pembelajaran diera new normal disesuaikan dengan satuan pendidikannya, apabila guru dan siswa memiliki sarana prasaran pembelajaran daring seperti HP, kuota internet dan lain sebagainya dan tidak memberatkan antara satu dengan lainnya maka dapat melaksanakan pembelajaran dalam jaringan (daring) dengan menggunakan aplikasi zoom, google classroom, wahtapp dan lain sebaginya yang dapat memberikan interaksi antara siswa dan guru.

Terkait dengan adanya pandemic covid-19 maka diperlukan perubahan media pembelajaran. Harus ada transformasi pemanfaatan media pembelajaran sehingga mampu beradaptasi dengan pandemic covid-19 sehingga proses pembelajaran tetap berlangsung meskipun peserta didik dan pendidik di rumah. Salah satu media yang mengalami transformasi adalah media televisi, yang awalnya manfaat media televisi digunakan untuk menarik minat pemirsa untuk menyaksikan berbagai tayangan yang ditampilakan mulai infotaiment, entertainment, film dan lain sebagainya. Fungsi media televisi sebagai media komunikasi sehingga memiliki peran secara fungsional untuk menyampaikan informasi, mendidik, menghibur dan memengaruhi. Masa pandemic covid19, kementerian pendidikan dan kebudayaan bekerjasama dengan TVRI menanyangkan program belajar di rumah. Artinya media telivisi mampu bertransformasi sebagai televise edukasi ditengan pandemic covid 19 (Gunawan, 2020). Hal ini menjadi terobosan dari pemerintah agar semua kalangan dapat menyelenggarakan pendidikan dimasa pandemic covid-19 ini.

Berdasarkan kondisi ekonomi dan letak geografis yang berbeda maka kenyataannya ada beberapa kondisi masyarakat yang memiliki keterbatasan dalam penggunaan internet. Ada beberapa masalah dan kendala yang dihadapi oleh guru maupun orang tua dalam pelaksanaan pembelajaran jarak jauh berbasis online. Adapun masalah yang dialami guru selama pelaksanaan pembelajaran di rumah menurut (Wijoyo, H., \& Indrawan, 2020) diantaranya 1) tidak ada pedoman yang pasti dalam mengajar jarak jauh; 2) keterbatasan kuota internet dan sinyal; 3) kesulitan dalam memberikan laporan perkembangan anak. Sedangkan masalah yang dihadapi orang tua diantaranya 1) orang tua yang memiliki anak lebih dari satu sedangkan Handphone hanya satu; 2) orang tua tidak terbiasa mendampingi anak dalam proses belajar sehingga menimbulkan rasa stress pada orang tua; 3 ) orang tua juga harus memikirkan kelangsungan hidup dan pekerjaan dimasa pandemic. Disatu sisi juga ada beberapa kendala dalam pelaksanaan pembelajaran jarak jauh (daring) diantaranya 1) banyak guru dan murid yang berada didaerah terpencil tidak memiliki Hp android; 2) ada sebagian desa yang tidak memiliki akses listrik; 3) sosialisasi pembelajaran jarak jauh secara online kepada guru dan orang 
tua kurang maksimal; (4) banyak orang tua, guru yang merasa keberatan dalam membeli Hp android, memasang internet d ruamah maupun membeli kuota internet; (5) ada sebagian guru yang tidak terlalu faham dengan pelaksaan pembelajaran system online; (6) banyak orang tua juga yang belum terbiasa dalam penggunaan $\mathrm{Hp}$ android.

Berdasarkan permasalah diatas maka perlu diadakan kegiatan Workshop Virtual Pengembangan Desain Pembelajaran Jarak Jauh dalam menghadapi New Normal bagi seluruh guru pada jenjang TK-SMA. Pembelajaran jarak jauh tidak harus pembelajaran secara daring, ada juga pembelajaran jarak jauh luar jaringan/offline (luring) dengan menggunakan media pembelajaran televisi, radio, modul belajar mandiri, lembar kerja, bahan ajar cetak, alat peraga dan media belajar dari benda di lingkungan sekitar. Guru dapat memberikan pembelajaran yang bervariasi agar anak-anak termotivasi untuk tetap belajar. Sehingga tujuan kegiatan workshop virtual ini adalah 1) Membantu para guru dalam menyusun Rencana Pelaksanaan Pembelajaran pada pembelajaran daring, luring maupun kombinasi agar guru memiliki pedoman disetiap pelaksanaan proses pembelajaran; 2) Membantu para guru dalam membuat bahan ajar pada pembelajaran daring, luring, ataupun kombinasi; dan 3) Membantu para guru dalam menggunakan media pembelajaran secara daring, luring maupun kombinasi.

\section{Metode}

Pengabdian masyarakat ini dilaksanakan dalam bentuk Workshop yang dilakukan secara virtual atau daring. Metode yang digunakan adalah partisipatif, peserta mengikuti penuh seluruh rangkaian kegiatan, baik penyampaikan materi maupun tugas-tugas mandiri. Seluruh materi disampaikan secara virtual melalui aplikasi Zoom Cloud Meeting, sehingga peserta bisa berinteraksi secara langsung. Seluruh materi dan tugas yang harus dikerjakan oleh peserta disampaikan melalui Google Classroom. Peserta mengerjakan tugas yang diberikan secara mandiri sebagai umpan balik (feedback) dalam bentuk perangkat pembelajaran RPP dan bahan ajar baik secara daring, luring maupun kombinasi. Peserta yang mengikuti workshop dapat mengakses materi melalui zoom, live facebook dan live streaming youtube.

Pelaksanaan pengabdian masyarakat workshop virtual pengembangan desain pembelajaran jarak jauh dilakukan dalam waktu tiga hari. Materi yang akan disampaikan pada workshop ini adalah 1) masalah dan solusi pendidikan jarak jauh; 2) desain pembelajaran jarak jauh (RPP dan bahan ajar daring, luring maupun kombinasi mulai dari sekolah jenjang TK, SD, SMP dan SMA), 3) pemenfaatan media dan pengembangan evaluasi pembelajaran jarak jauh. Materi yang akan menjadi tugas peserta workshop adalah materi kedua yaitu desain pembelajaran jarak jauh (bahan ajar dan RPP). Tugas dilanjutkan pada Google Classroom, semua peserta dan pemateri wajib masuk di Google Classroom agar bisa berdiskusi tentang tugas yang wajib dikumpulkan sebagai syarat pengambilan sertifikat workshop. Peserta diberi waktu tiga hari setelah kegiatan workshop untuk menyelesaikan tugas membuat RPP dan Bahan ajar baik daring, luring maupun kombinasi dan dikumpulkan di Google Classroom. Panitia workshop akan melihat dan menilai hasil tugas peserta dan memilih tugas yang terbaik dari setiap jenjang sekolah mulai TK, SD, SMP dan SMA. 


\section{Hasil dan Pembahasan}

Pelaksanaan kegiatan pengabdian masyarakat "pengembangan desain pembelajaran jarak jauh" dilaksanakan melalui aplikasi Zoom Meeting yang sudah disiapkan di media center Unipa Kampus Lamongan. pengabdian masyarakat ini melibatkan dosen, guru dan praktisi pendidikan sebayak 300 dari beberapa Kabupaten dan kota di Indonesia. Sebagaian besar peserta berasal dari Kota Lamongan, Bojonegoro, Tuban,Trenggalek, Sidoarjo, Surabaya . Pengabdian masyarakat ini bekerjasama dengan PGRI Lamongan agar dapat tepat sasaran khususnya guru di Lamongan dan umumnya seluruh guru di Indonesia. Kegiatan PKM ini dikuti oleh guru dari berbagai tingkatan di sekolah. Adapun perbandingan peserta workshop dapat dilihat dari tingkatan sekolah tempat peserta bekerja adalah sebagai berikut:

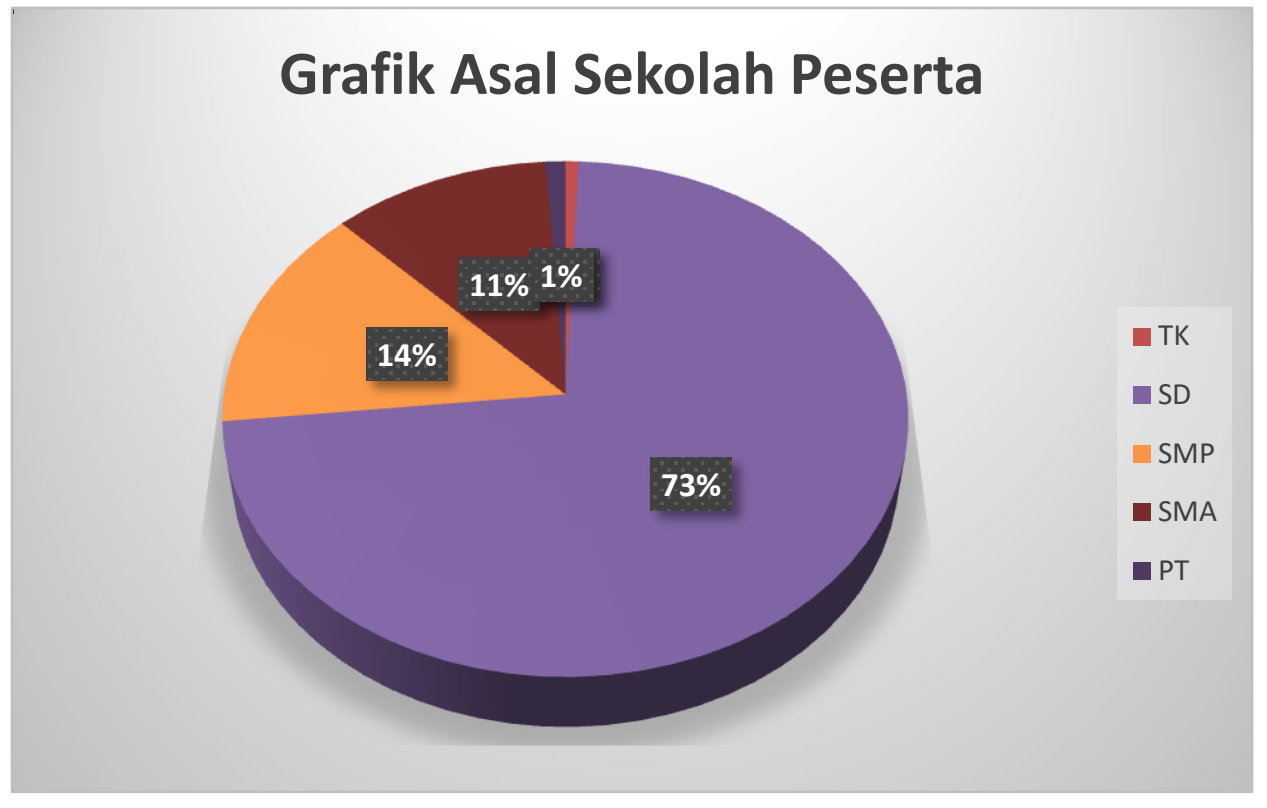

Gambar 1. Grafik Peserta di lihat dari Asal Sekolah

Berdasarkan grafik diatas dapat lihat bahwa $73 \%$ peserta workshop berasal dari jenjang Sekolah Dasar (SD). Hal ini menunjukkan bahwa meskipun ditengah pandemic para guru di Indonesia sangat berantusias dalam meningkatkan potensi diri dalam menyambut pendidikan ajaran baru pada masa new normal .

Proses pelaksanaan kegiatan PKM dilakukan melalui 6 tahap yaitu 1) penyebaran informasi selama dua minggu; 2) pendaftaran peserta melalui google form; 3) pelaksanaan kegiatan (materi dan praktek); 4) penugasan praktek; 5) evaluasi dan asesmen; 6) penutup. Implementasi dari 6 tahapan diatas diuraikan sebagai berikut:

1. Penyebaran informasi

Kegiatan pengabdian masyarakat ini dilaksanakan di tengah pandemic covid-19 oleh sebab itu penyebaran informasi juga dilaksanakan secara online. Penyebaran informasi melalui poster template yang disebarkan dibeberapa media social diantaranya facebook, status dan grup whatsapp, Instagram dan lain sebagainya. Adapun poster template workshop dapat dilihat pada gambar dibawah ini 


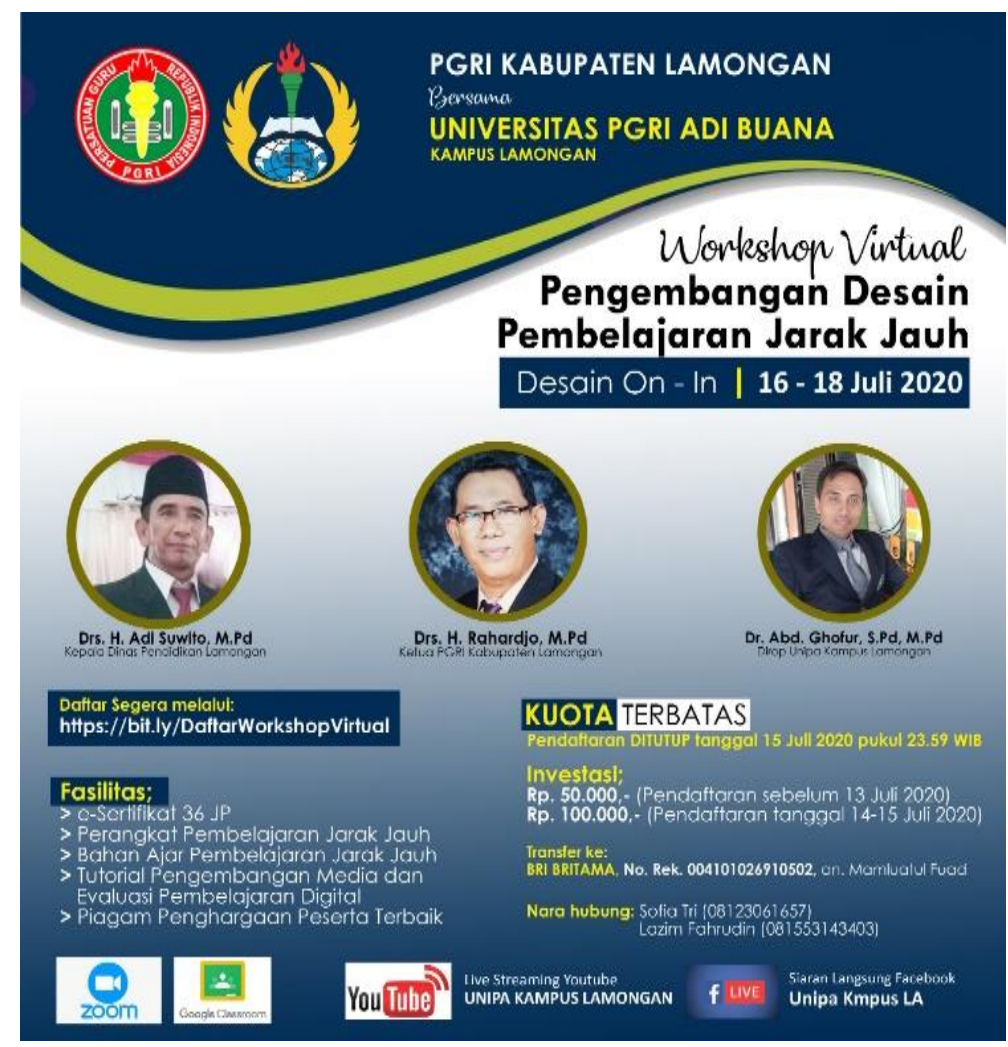

Gambar 2. Poster Tamplate untuk Promosi

Dari 300 Jumlah peserta workshop, rata-rata informasi kegiatan tersebut diperoleh melalui grup whatsapp dan facebook. Adapun distribusi sebaran informasi kegiatan PKM ini adalah sebagai berikut

\section{DISTRIBUSI INFORMASI KEGIATAN WORKSHOP}

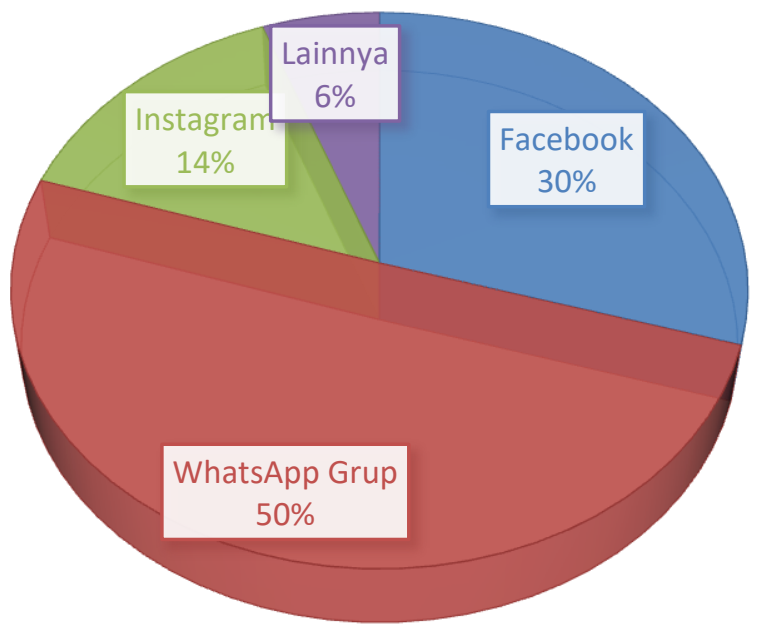

Gambar 3. Distribusi Informasi Kegiatan Workshop melalui Media Sosial 
2. Pendaftaran peserta workshop

Bagi para peserta kegiatan PKM dapat melakukan registrasi secara online melalui laman https://forms.gle/7ohToLWcuuendS4S8. Selanjutnya peserta akan dibuatkan grup whatsapp dan google classroom agar memudahkan para peserta dalam komunikasi dengan panitia dan narasumber untuk menyelesaikan tugas workshop. Jumlah grup whatsapp sebanyak tiga grup dan dua google classroom. Kegiatan PKM ini bekerjasama dengan PGRI Kabupaten Lamongan karena awalnya dipersiapkan untuk guru Kabupaten Lamongan, tetapi dalam prakteknya setelah dibuka pendaftaran online tidak hanya guru Kabupaten Lamongan saja melainkan hampir seluruh guru di Indonesia bahka tidak hanya guru, ada juga peserta dari kalangan dosen, mahasiswa dan praktisi pendidikan lainnya yang ikut serta dalam kegiatan PKM pengembangan desain pembelajaran jarak jauh ini.

Kegiatan PKM ini sesuai dengan tujuannya yaitu mengembangkan desain pembelajaran jarak jauh. Adanya pandemic covid 19 ini pemerintah telah mengeluarkan kebijakan pembelajaran jarak jauh di masa new normal. Secara tidak langsung pandemic ini mendorong seluruh praktisi pendidikan untuk menyesuaikan dengan revolusi industry 4.0. Kompetensi yang harus dimiliki pendidik dan tenaga kependidikan salah satunya pergeseran dari hard skill ke soft skill. Adanya system database global memudahkan seseorang dalam mengakumulasi pengetahuan dan informasi dengan mudah. Pendidik dapat menelurusi dengan mudah untuk mencari bahan ajar yang sesuai dan menarik minat belajar peserta didiknya dan sebaliknya, peserta didik juga menelusuri internet untuk mengerjakan tugas yang diberikan oleh guru. Para Pendidik harus bisa menciptakan lingkungan belajar di era new normal untuk mendukung terjadinya proses belajar mandiri dan bermakna sehingga tujuan belajar mandiri tercapai (Sulisworo, D., Winarti, W., Amalia, Y. A., Larekeng, S. H., Maryani, I., \& Demitra, 2020)

3. Pelaksanaan Kegiatan

Pelaksanaan Kegiatan PKM ini diisi dengan pembekalan materi dan praktek secara langsung oleh para narasumber. Kegiatan ini dilaksanakan dalam waktu tiga hari mulai jam 08.00 s.d 11.00 WIB. Adapun materi di hari pertama yaitu tentang kebijakan pendidikan Kabupaten Lamongan, prinsip-prinsip pembelajaran jarak jauh dan permasalahan serta solusi pembelajaran jarak jauh yang sampaikan oleh Dr. Abd. Ghofur, S.Pd, M.Pd dan Dr. H. Ahmad Sidi, MM. materi kedua yaitu penyusunan rencana pembelajaran jarak jauh dan pembuatan bahan ajar pembelajaran jarak jauh yang disampaikan oleh Durrotun Nafisah, S.Pd, M.Pd, Ety Youhanita, S.Pd, M.Pd dan Dra.Ninies Eryadin,M.Pd. Sedangkan materi dihari ketiga adalah pemanfaatan media pembelajaran jarak jauh dan pengembangan evaluasi pembelajaran jarak jauh yang disampaikan oleh Evi Aulia Rachma, S.Pd, M.Pd dan Kuswanto, S.Kom, MM.

Setelah tiga hari kegiatan selesai maka dilanjutkan tugas mandiri selama tiga hari untuk mengerjakan tugas yaitu membuat RPP dan bahan ajar pembelajaran jarak jauh. Tugas mandiri didiskusikan dan dikumpulkan di google classroom. Bagi peserta yang sudah menyelesaikan tugas mandiri bisa mendownload sertifikat yang sudah 
BERNAS:

Jurnal Pengabdian Kepada Masyarakat

disediakan oleh panitia. Total jam dari kegiatan workshop virtual pengembangan desain pembelajaran jarak jauh sebanyak 36 JP yang tertera di sertifikat.

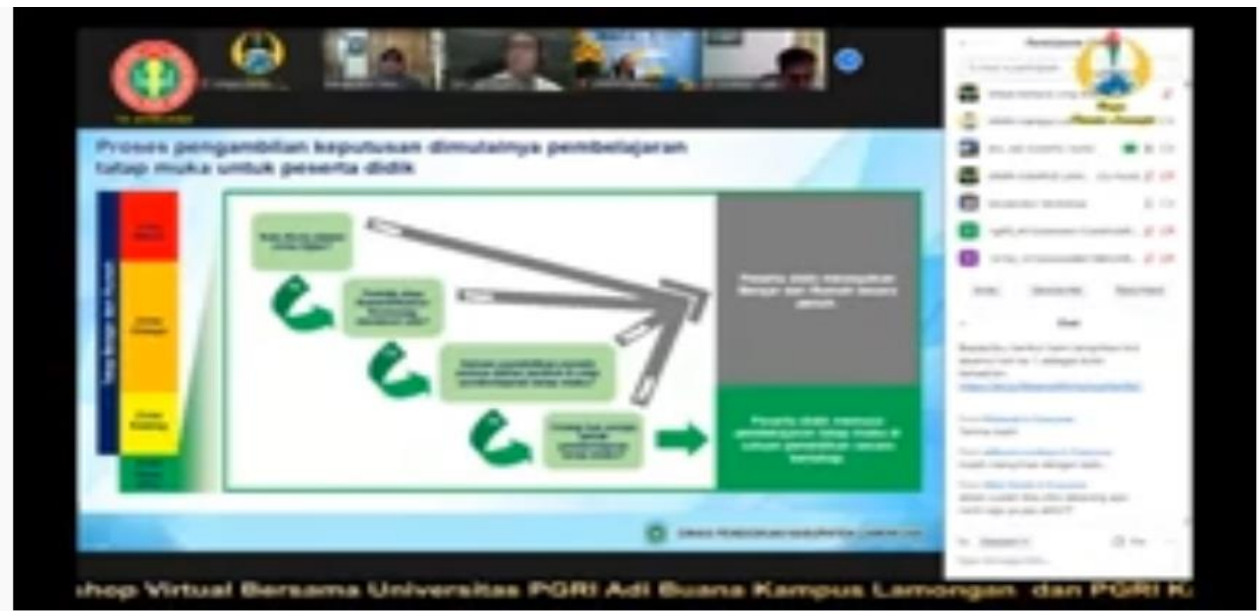

Workshop Virtual "Konsep Pendidikan Jarak Jauh : Masalah dan Solusi" hari 1

Gambar 4. Kegiatan Workshop virtual di hari pertama materi kebijakan pembelajaran jarak jauh
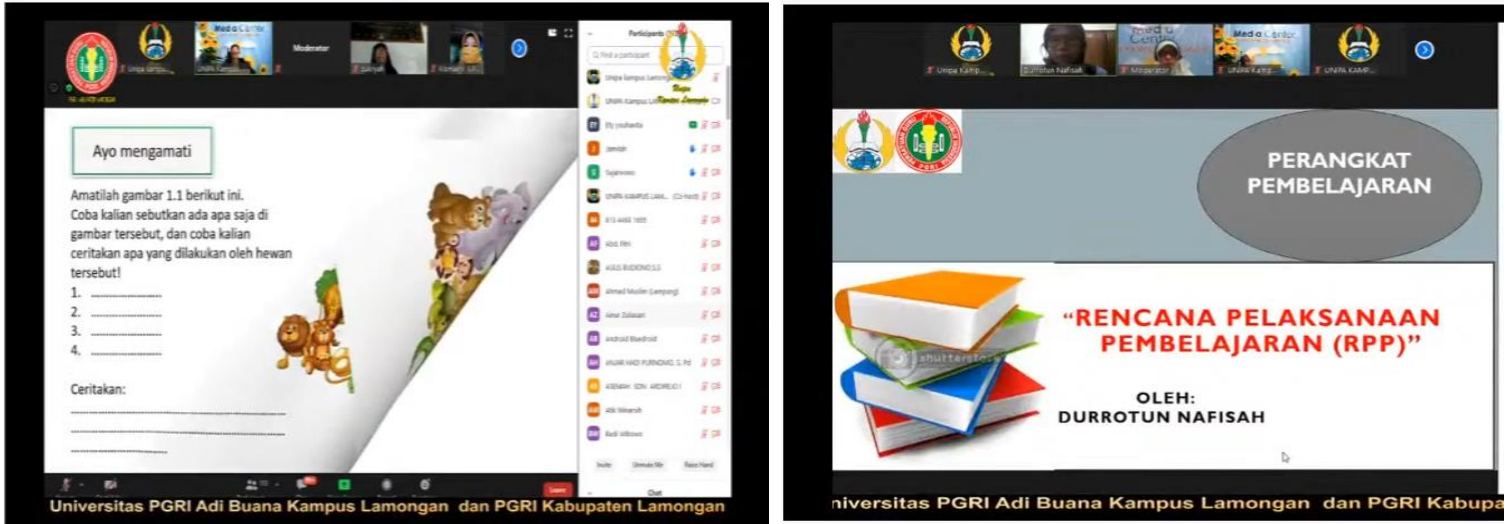

Gambar 5. Kegiatan Workshop hari kedua materi perangkat pembelajaran dan bahan ajar pembelajaran jauh
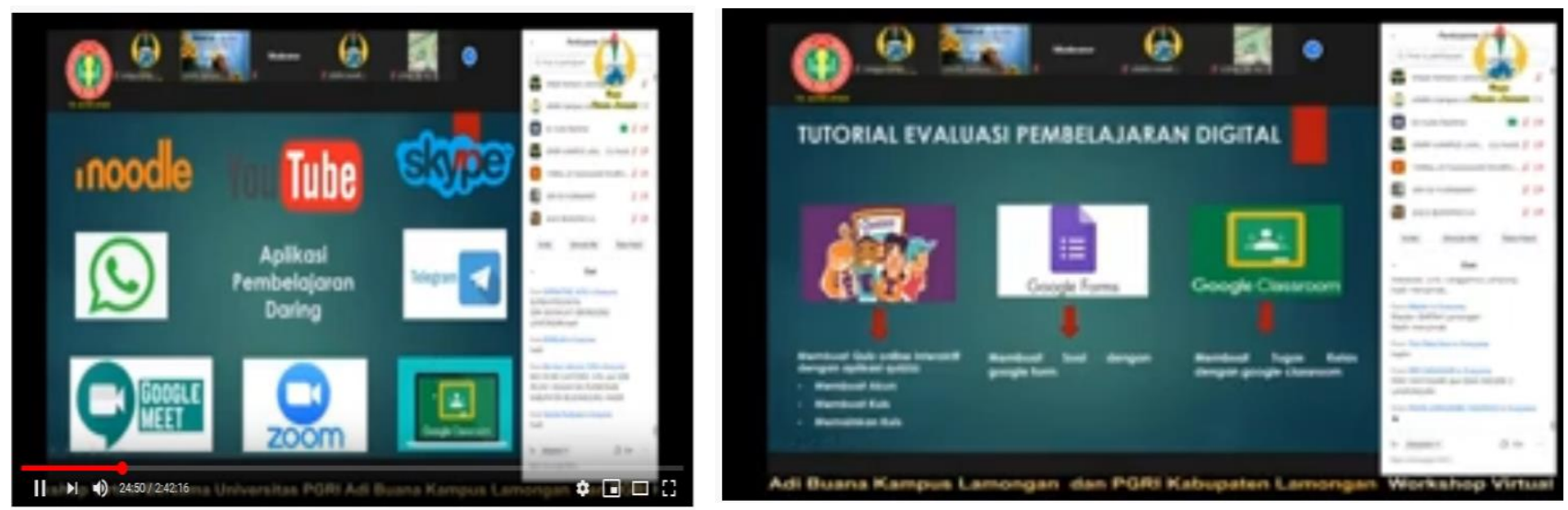

Gambar 6. Kegiatan Workshop hari ketiga materi media dan evaluasi pembelajaran jarak jauh 
4. Penugasan Praktek

Setelah kegiatan materi dan praktek langsung oleh nara sumber maka kegiatan selanjutnya adalah latihan mandiri di rumah masing-masing selama tiga hari untuk mengerjakan tugas membuat perangkat pembelajaran dan bahan ajar pembelajaran jarak jauh yang disesuaikan dengan satuan pendidikannya masing-masing dan kondisi peserta didiknya. Peserta didik bisa berdiskusi dengan narasumber di google classroom apabila ada kendala dalam menyelesaikan tugas. Tugas juga dikumpulkan di google classroom sesuai waktu yang sudah ditentukan oleh panitia.

5. Evaluasi dan asesmen

Kegiatan evaluasi dilaksanakan secara daring, dengan mengisi angket oleh seluruh peserta yang sudah disediakan panitia. Adapun isi angket diantaranya bagaimana konsep pembelajaran jarak jauh, desain pengembangan perangkat pembelajaran jarak jauh serta evaluasi terhadap pelaksanaan kegiatan PKM ini. Berdasarkan hasil evaluasi kegiatan seluruh peserta menyatakan bahwa kegiatan PKM ini memberikan manfaat kepada mereka dalam menyiapkan pembelajaran di era new normal. Disamping itu, ada kendala yang dialami saat pelaksanaan PKM diantaranya kendala teknis jaringan dan listrik di hari kedua sehingga waktu pelaksanaan sampai pukul 14.30 karena padamnya listrik se Jawa Bali. Sehingga untuk pelaksanaan PKM selanjutnya dapat ditingkatkan.

Selain evaluasi ada juga asesmen terhadap tugas yang sudah diberikan para peserta. Dari 300 peserta yang mengikuti kegiatan ini $100 \%$ peserta sudah mengumpulkan tugas di google classrom. Adapun contoh tugas yang sudah dukumpulkan dari salah satu peserta tentang bahan ajar daring sebagi berikut:

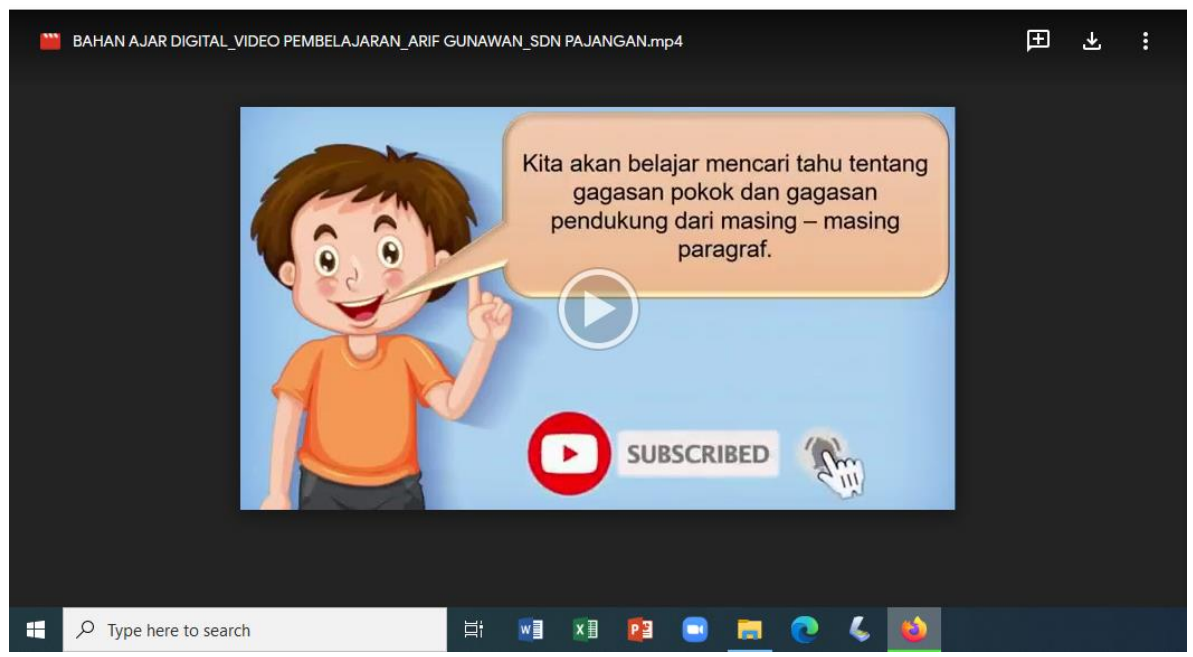

Gambar 7. Bahan Ajar Pembelajaran Jarak Jauh

6. Penutup

Kegiatan PKM Desain Pembelajaran jarak jauh langsung ditutup oleh Direktur Operasional Unipa Kampus Lamongan melalui aplikasi zoom meeting. Sebelum 
kegiatan ditutup para peserta bisa berdiskusi langsung baik dengan narasumber maupun peserta lainnya. Di penutup ini juga akan diumumkan pemenang atau tugas terbaik yang sudah dipih oleh beberapa narasumber. Bagi peserta yang memiliki nilai baik akan diberikan penghargaan berupa sertifikat. Mengacu pada hasil evaluasi kegiatan PKM "Pengembangan Desain Pembelajaran Jarak Jauh" dapat diketahui bahwa masih banyak guru yang perlu diberikan pelatihan atau workshop terkait Desain Pembelajaran Jarak jauh yang berbentuk daring. Karena guru professional selain harus memiliki kompetensi dalam melaksanakan tugas guru juga harus menguasai keahlian, kemampuan beradaptasi dengan teknologi baru dan tantangan global (Yuara, Rizal, \& Kusumaningrum, 2019). Dengan adanya pandemic covid 19 secara tidak langsung juga mendorong para guru dalam menerapkan kurikulum 2013. Karena guru diharapkan mampu menguasai dan menerapkan teknologi dalam proses pembelajaran (Sukaesih, Ridlo, \& Saptono, 2017). Pada abad 21 ini Indonesia menyongsong generasi emas pada usia emas dengan melakukan penyempurnaan kurikulum dan peningkatan profesionalisme guru (Mahanal, 2014).

\section{Kesimpulan}

Kegiatan Pengabdian Kepada Masyarakat ini berjalan dengan baik sesuai jadwal yang sudah ditetapkan, serta mendapat tanggapan positif yang baik dari seluruh peserta. Sebanyak 300 peserta kegiatan ini berasal dari berbagai wilayah Indoensia serta dari berbagai profesi diantaranya guru, Dosen, dan praktisi pendidikan. Berdasarkan hasil analisis kegiatan bahwa $100 \%$ peserta mengumpulkan tugas dan mendapat sertifikat. Dengan adanya kegiatan ini menambah wawasan kepada guru bahwa pelaksanaan pembelajaran jarak jauh dapat dilaksanakan secara daring, luring dan kombinasi. Semua itu dapat disesuaikan dengan kondisi geografis dan peserta didik di masing-masing satuan pendidikan. Peserta didik mendapat materi konsep pembelajaran jarak jauh, rencana pembelajaran dan bahan ajar serta media dan evaluasi pembelajaran jarak jauh. Namun, ada beberapa kendala yang dialami para peserta diantaranya pembelajaran jarak jauh daring. Karena pada kurikulum 2013 guru juga diharapkan mampu menguasai dan menerapkan teknologi dalam proses pembelajaran. Sehingga diperlukan pelatihan selanjutnya tentang pemanfaatan teknologi informasi dan komunikasi (TIK) dalam proses pembelajarang jarak jauh secara daring.

\section{Daftar Pustaka}

Dewi, W. A. F. (2020). Dampak COVID-19 terhadap Implementasi Pembelajaran Daring di Sekolah Dasar. Edukatif: Jurnal IImu Pendidikan, 2(1), 55-61. https://doi.org/10.31004/edukatif.v2i1.89

Firmansyah, Y., \& Kardina, F. (2020). Pengaruh New Normal Ditengah Pandemi Covid-19. BUANA ILMU, 4(2), 99-112., 4(2), 99-112.

Ilmiyah, S. (2020). Surotul IImiyah -Upaya PBNU Mencegah PenyebaranCOVID-19. (p. YouTube alobatnic: https://youtu.be/rYlypLWR3Qw). p. YouTube alobatnic: https://youtu.be/rYlypLWR3Qw.

Mahanal, S. (2014). Peran Guru dalam Melahirkan Generasi Emas dengan Keterampilan 
Abad 21. Seminar Nasional Pendidikan HMPS Pendidikan Biologi FKIP Universitas Halu Oleo, 20(September), 1-16.

Nuryatin, S. (2020). Adaptasi Metode Pembelajaran Melalui E-Learning Untuk Menghadapi Era New Normal. Retrieved from http://repositorio.unan.edu.ni/2986/1/5624.pdf

Sa'adah. (2020). Tinjauan Tentang Skenario Pembelajaran Tahun Pelajaran 2020 / 2021 Di Kabupaten Lombok Timur. Jurnal IImu Sosial Dan Pendidikan, 4(3), 447-456.

Sukaesih, S., Ridlo, S., \& Saptono, S. (2017). Analisis kemampuan technological pedagogical and content knowledge(TPACK) calon guru. Seminar Nasional Pendidikan Sains, 21, 58-64.

Sulisworo, D., Winarti, W., Amalia, Y. A., Larekeng, S. H., Maryani, I., \& Demitra, D. (2020). Model lingkungan pembelajaran era new normal.

Wijoyo, H., \& Indrawan, I. (2020). Model Pembelajaran Menyongsong New Era Normal Pada Lembaga Paud Di Riau. JS (Jurnal Sekolah) Universitas Negeri Medan, 4(3), 205-212. https://doi.org/https://doi.org/10.24114/js.v4i3.18526

Yuara, Y. P., Rizal, F., \& Kusumaningrum, I. (2019). Kesiapan Guru Vokasi Smkn 1 Sumatera Barat Dalam Menghadapi Era Revolusi Industri 4 . 0. Jurnal Ilmiah Dan Pembelajaran, 3(3), 280-288. 